\title{
Being and Doing: A Study of Status Responsibility and Voluntary Responsibility
}

John R. Silber

The debt owed H. L. A. Hart by lawyers and philosophers and by the general public through them grows exponentially, it seems, with every stroke of his active pen. Particularly outstanding contributions to contemporary thought are Hart's extensive writings on the highly complex relationship between morality and law, on his discussions of moral and legal responsibility, and on the proper role of mens rea in determining who should be punished. Hart writes, for example, that: "[]]n a civilized [legal] system only those who could have kept the law should be punished," and that the "individual ... has a right not to be [punished] unless he could have avoided doing what he did." In presenting these views Hart speaks for most moral philosophers no less than for the majority of the legal profession. Contemporary minds seem to be united in their rejection of any theory of responsibility that depends upon a notion of status responsibility ${ }^{2}$-a view which permits of finding men morally wrong and blameworthy for their diseased condition or state of being in the absence of any morally blameworthy conduct that might have been avoided. The legal definition of criminal conduct and the contemporary philosophical view of moral obligation are based on the concept of voluntary responsibility, according to which man is morally wrong and blameworthy, not for what he is, but for what he does or is able to avoid doing.

Although the conceptions of status and voluntary responsibility are both enshrined in mythological lore (the former, for instance, in the fall of Adam and the doctrine of original sin, and the latter in the revolt of Prometheus), it is a curious and important historical fact that the conception of voluntary responsibility has become dominant in both ethics and criminal law, while the conception of status responsibility has scarcely survived. While one has been commended

John R. Silber is Chairman of the Department of Philosophy and the Program of Comparative Studies and is Professor of Arts and Letters at the University of Texas.

1 H.L.A. HART, The MORALITY OF THE CRIMINal LAW 8, 27 (1965) (emphasis in original).

2 "Status" here means the (legal) condition or state of being of a person, not, of course, his social status or prestige. 
for its advance beyond primitive notions, the other has been condemned as primitive and rejected, as Hart argues, on the grounds that it is itself an immoral notion. And if status responsibility has not been totally rejected by criminal courts, lawyers and legal theorists, it is accepted into criminal law only under severe limitations, with grave doubts over strong opposition, and for extra-moral political and social considerations.

Following a very brief survey of law and ethics to introduce some empirical support for these observations, I shall try to show that while neither the voluntary nor the status conception of responsibility is satisfactory by itself, both are required with modifications in the formulation of a sound theory of responsibility. I shall argue that recent tort law provides useful guidelines for the extension of the concept of mens rea and for the development of a concept of responsibility that gives proper place to status elements. And throughout the paper, I shall use-either as a guide or a counter-Hart's concise statement of the essentially voluntary character of moral responsibility in ascertaining the role and scope of voluntary elements of awareness, intention, choice and control in human action. Although some of my disagreements with Hart are fundamental, most involve differences of emphasis or degree, and all have developed out of periods of informative struggle with his ideas.

In common law countries it is taken for granted that no man should be treated as a criminal or convicted of a crime unless he has done something wrong and knew what he was doing. Generally speaking, the behavior of a man is to be treated as criminal conduct only if there is a concurrence of mens rea, the awareness of the wrongfulness or unlawfulness of the conduct, and actus reus, the physical manifestation of mens rea. ${ }^{3}$ With rare exceptions, no act or occurrence can be criminal unless the basic functions of intelligence and volition are present. The consensus of legal thinking on this point is well summarized by Professor Herbert Packer:

To punish conduct without reference to the actor's state of mind is both inefficacious and unjust. It is inefficacious because conduct unaccompanied by an awareness of the factors making it criminal does not mark the actor as one who needs to be subjected to punishment in order to deter him or others from behaving similarly in the future, nor does it single him out as a socially dangerous individual who needs to be in-

3 J. Hall, General Principles of Criminal Law 70, 179, 230, 251 (2d ed. 1960). 
capacitated or reformed. It is unjust because the actor is subjected to the stigma of a criminal conviction without being morally blameworthy. ${ }^{4}$

Generally speaking criminal sanctions are to be applied only in those situations in which moral blame would be appropriate. If criminal punishment is understood, in the words of Professor H. M. Hart, as "a formal and solemn pronouncement of the moral condemnation of the community,"' then we can more easily understand and accept the moral indignation and high-pitched rhetoric of the district attorney as an expression of the lawyer's professional sense of the dependence of criminal law on morality. And unless morality makes provision for status offenses and status responsibility, we should find in criminal law a tendency to deny legal force to status crimes or status reponsibility.

Morality, as interpreted by most contemporary philosophers, makes no such provisions. H. L. A. Hart, in complete argreement with Kant, lists among the distinctive features of morality the "voluntary character of moral offenses." In developing this point, Hart writes:

If a person whose action, judged $a b$ extra, has offended against moral rules or principles, succeeds in establishing that he did this unintentionally and in spite of every precaution that it was possible for him to take, he is excused from moral responsibility, and to blame him in these circumstances would itself be considered morally objectionable. Moral blame is therefore excluded because he has done all that he can do. ... [I]n morals "I could not help it" is always an excuse, and moral obligation would be altogether different from what it is if the moral "ought" did not in this sense imply "can."7

In due course I shall examine Hart's statement in detail. For the moment, however, I enter it in the record as a clear statement of the generally accepted view of the essentially voluntary character of moral responsibility-a character which makes lawyers properly reluctant to apply criminal sanctions in a situation unless there is an action that is voluntary and intentional. Lawyers would be prone, moreover, to excuse any action that is unintentional, undertaken with due care and precaution, or unavoidable.

4 Packer, Mens Rea and the Supreme Gourt, 1962 SUP. Cr. Rev. 107, 109; cf. MODEL Penal Code § 2.05, Comment (Tent. Draft No. 4, 1955).

5 H.M. Hart, The Aims of the Criminal Law, 23 LAw \& Contemp. Prob. 401 (1958).

6 H.L.A. HART, THE CONCEPT OF LAW 173 (1961).

T Id. at 173-74 (1961). 
This is illustrated by the decision of the Supreme Court in Robinson $v$. California. ${ }^{8}$ Robinson was convicted under a California statute which made narcotics addiction a criminal offense. Under the terms of the statute: "No person shall use, or be under the influence of, or be addicted to the use of narcotics, excepting when administered by or under the direction of a person licensed by the State to prescribe and administer narcotics." "9 During Robinson's trial, the judge instructed the jury that this statute made it an offense for a person "either to use narcotics, or to be addicted to the use of narcotics." The judge said further: "That portion of the statute referring to the 'use' of narcotics is based upon the 'act' of using. That portion of the statute referring to 'addicted to the use' of narcotics is based on a condition or status. They are not identical ... ."10 It was therefore unclear to the Supreme Court whether the jury found Robinson guilty of the act or merely the status condemned by the statute. In delivering the opinion of the Court, Justice Stewart complained that the statute is not one "which punishes a person for the use of narcotics, for their purchase, sale or possession, or for antisocial or disorderly behavior resulting from their administration." Rather, he said: "We deal with a statute which makes the 'status' of narcotic addiction a criminal offense ... . California has said that a person can be continuously guilty of this offense whether or not he has ever used or possessed any narcotics within the State, and whether or not he has been guilty of any antisocial behavior there."11

In order to categorize this statute properly, Justice Stewart considered whether it would be possible to "make it a criminal offense for a person to be mentally ill, or a leper, or to be afflicted with a venereal disease .... [I]n the light of contemporary human knowledge," he concluded, "a law which made a criminal offense of such a disease would doubtless be universally thought to be an infliction of cruel and unusual punishment. ..."12 $\mathrm{He}$ concluded that the statute under which Robinson was convicted fell into this same category because drug addiction is an illness, and that a law which "imprisons a person thus afflicted as a criminal, even though he has never touched any narcotic drug within the State or been guilty of any irregular behavior there, inflicts a cruel and unusual punishment. . . ."The length of imprisonment was held to be irrelevant. Justice Stewart

8370 U.S. 660, rehearing denied, 371 U.S. 905 (1962).

9 Cal. Hzartit \& Safety Code \$ 11721.

10370 U.S. at 662 .

11 Id. at 666.

12 Id. 
declared: "Even one day in prison would be a cruel and unusual punishment for the 'crime' of having a common cold."13

Justice Douglas, concurring, compared narcotic addiction to insanity. He noted that while insane people "may be confined either for treatment or for the protection of society, they are not branded as criminals."14 And he concluded:

I do not see how under our system being an addict can be punished as a crime. If addicts can be punished for their addiction, then the insane can also be punished for their insanity. Each has a disease and each must be treated as a sick person. ... He [the addict] may, of course, be confined for treatment for the protection of society. Cruel and unusual punishment results not from the confinement, but from convicting an addict of a crime. ... A prosecution for addiction, with its resulting stigma and irreparable damage to the good name of the accused, cannot be justified as a means of protecting Society, where a civil commitment would do as well. ${ }^{15}$

The opinions in Robinson $v$. California illustrate the abhorrence lawyers generally feel for status responsibility in criminal law and their refusal to use this concept in defining crime. The opinions reflect their confidence in and approval of the dominant concept of moral obligation which allows only for voluntary responsibility according to which only action or conduct (actus reus) that is voluntary and intentional (involving mens rea) can be morally blameworthy. Conditions of moral blameworthiness as defined by the voluntary conception of responsibility are accepted in Robinson $v$. California as limiting conditions for the application of criminal sanctions. The moral inappropriateness of blaming one for what he is rather than for what he does, indeed, the immorality of status responsibility, is seen to be the driving force behind the Court's decision. ${ }^{16}$

13 Id. at 667 .

$14 I d$. at 669 .

16 Id. at 674, 676, 677 (footnotes omitted) (emphasis in original).

Mr. Justice Harlan, concurring, did not agree that narcotics addiction is an illness nor, consequently, that to subject narcotic addicts to criminal sanctions would amount to cruel and unusual punishment. But, like Justices Stewart and Douglas, he denied the right of the state to convict a person for his addiction to narcotics rather than for their use. Since, according to Justice Harlan, addiction is not more than "a compelling propensity to use narcotics," 370 U.S. at 679 , he reasoned that the California court had in effect authorized "criminal punishment for a bare desire to commit a criminal act." Id. And he refused to permit the substitution of a wish following from status for an action, an actus reus, in the definition of a crime.

16 But the reluctance of our courts to use the concept of status responsibility in crim- 
It might seem, however, that a serious and extensive reliance on the concept of status responsibility in criminal law is found in those cases in which a person may be convicted of a crime and suffer criminal sanctions on the basis of strict liability. Many laws concerned with public welfare-e.g., laws pertaining to food adulteration or mislabeling of drugs-permit criminal conviction in cases where there is complete absence of mens rea and even absence of actus reus by the accused. ${ }^{17}$ But even this is not a serious exception to my general point about the criminal law's avoidance of status responsibility, for the criminal law is nowhere under more vigorous or sustained attack both from within, in actual litigation, and from without, in legal scholarship, than in its reliance on strict liability. ${ }^{18}$

Even so it must be acknowledged that there is an increasing reliance on strict liability in tort law, particularly in cases involving the determination of responsibility for defective products, and this develop-

inal cases has not been universal. Many states using the common law have applied criminal sanctions to the offense of vagrancy. Prior to Robinson $v$. California, a vagrant could be anyone from a healthy beggar, ALA. CODE tit. 14, 437 (1958), to a prostitute, TEX. PEN. Code art. 607 (1952), to a narcotics user, N.J. REv. STAT. \& 2A:170-78 (1953) ("disorderly person"); see Dubin \& Robinson, The Vagrancy Concept Reconsidered, 37 N.Y.U.L. REv. $102,109-13$ (1962) (exhaustive list of categories). It is clear that such laws punish a state of being or a condition and abandon the requirement of conduct, actus reus, in the definition of the criminal offense. Confinement for vagrancy is a punishment, in the words of Justice Holmes, for "being a certain kind of person, not [for] doing a certain overt act . . . [ [I]t follows ... that ... the conduct proved is not the offense but only a ground of inference." Commonwealth v. O'Brien, 179 Mass. 533, 534, 61 N.E. 213, 214 (1901) (emphasis supplied). Not only Robinson $v$. California stands in opposition to crimes of status; this opposition is also found in the Model Penal Cocle and in the Uniform Narcotic Drug Act.

17 In United States v. Dotterweich, 320 U.S. 277 (1943), the Supreme Court recognized the validity of a law which, in the words of the Court, "dispenses with the conventional requirement for criminal conduct-awareness of some wrongdoing." Id. at 281. Fere the Court upheld the criminal conviction of Dotterweich, president of a company that had made two interstate shipments of drugs that were. either mislabeled or adulterated, although it had not been shown that Dotterweich was either personally aware of the mistaken shipments or negligent in his administration of the company. In United States $v$. Balint, 258 U.S. 250 (1922), and United States v. Behrman, 258 U.S. 280 (1922), the Supreme Court construed the Harrison Narcotics Act to mean that knowledge that one was selling narcotics was not an element in the offense of selling them. The Court raised no objection to the provision of the five years' imprisonment as the maximum penalty under the statute for an offense which could be proved against a person who did not knowingly engage in the activity proscribed by the statute. (It should be noted that the issue of imprisonment was not raised on appeal by the parties in Balint.)

18 See, e.g., J. Hail, General Principles of Criminal Law 342.51, 375 (2d ed. 1960); H.L.A. Hart, ThE Concept of LAw 168-69, 173-75 (1961); G. WhLIAMs, Criminal LaW $\$ \$ 70-76,81$ (1953); H.M. Hart, The Aims of the Criminal Law, 23 LAW \& Contemp. Prob. 401, 422-25 (1958); Packer, Mens Rea and the Supreme Court, 1962 Sup. Cr. REv. 107, 109-10, 147-48; Sayre, Public Welfare Offenses, 33 Colvas. L. REv. 55 (1933); Wasserstrom, Strict Liability in the Criminal Law, 12 Stan. L. Rev. 731 (1960); Model Penal. Code $\$ 2.05$ and Comment at 140 (Tent. Draft No. 4, 1955). 
ment has not brought shrill objection from legal scholars. But here again I find no more than a highly qualified exception to my descriptive point about the rejection of status responsibility in criminal law. In the first place, tort law is a branch of civil, not criminal law: the defendant in a tort action is neither indicted by a grand jury of fellow citizens nor accused of a crime and prosecuted by a public official. And most important, he is not subject to a criminal sanction of fine or imprisonment; a judgment against him does not ipso facto imply an assumption of his moral blameworthiness or the stigma of criminal conviction. ${ }^{19}$ In the second place, the courts have justified their reliance on strict liability in tort actions either on the principle of overriding public welfare, or on grounds which reveal varying degrees of personal responsibility by tortfeasors even though, admittedly, the degrees would be insufficient to sustain the ascription of personal responsibility on the basis of the voluntary conception of responsibility.

To illustrate, in Suvada $v$. White Motor Company, ${ }^{20}$ we find the court saying:

Recognizing that public policy is the primary factor for imposing strict liability on the seller and manufacturer of food in favor of the injured consumer, we come to the crucial question in this case, namely, is there any reason for imposing strict liability in food cases and liability based on negligence in cases involving products other than food. . . Without extended discussion, it seems obvious $[a]$ that public interest in human life and health, $[b]$ the invitations and solicitations to purchase the product and $[c]$ the justice of imposing the loss on the one creating the risk and reaping the profit are present and as compelling in cases involving motor vehicles and other products, where their defective condition makes them unreasonably dangerous to the user, as they are in food cases. ${ }^{21}$

In this opinion there is no suggestion that moral blameworthiness attaches to the defendant. The court speaks of "imposing the loss" not of "imposing the blame" or "imposing the penalty." In [a] the court stresses merely the important public concern that products which are advertised and sold be safe for public use. In $[b]$ and $[c]$ the court

19 This is not to deny that some acts that give rise to tort litigation do involve the moral blameworthiness of the agent.

2032 Ill. 2d 612, 210 N.E.2d 182 (1965).

21 Id. at 618-19, 210 N.E.2d at 186 (brackets inserted). I wish here to thank Professor Wayne Thode of the University of Texas School of Law for informing me of the extensive use of strict liability in tort law, and for his general criticisms of this paper. 
points out that the party who creates the risk (whether by manufacture, advertising, sale, etc.) and reaps the profit is in justice the one to bear whatever loss may be incurred if such products are defective. Here the court recognizes responsibility for a loss even though the loss is not the consequence of a voluntary, intentional act. The manufacturer or seller of a defective product is responsible for the loss, not because voluntarily or through negligence he occasioned the loss, but because he is the one who shaped the situation in which the loss might occur. The status of the manufacturer or seller rather than a specific act of his provides the basis of his responsibility; and yet the manufacturer or seller creates his status through prior acts even though those acts have nothing directly to do with the loss. This is, then, a model of responsibility which does not fit the model of either voluntary or status responsibility, but rather suggests a conception of responsibility containing elements of both. This model should commend itself to the attention of philosophers and criminal lawyers for having at least some of the subtlety and complexity characteristic of human life.

It will be seen, I believe, that this conception of responsibility in tort law is appropriate for the concept of human action which I wish to support. But it cannot be regarded as a qualification of my basic point that in both criminal law and contemporary ethics there has been, generally, a rejection of status responsibility and an assumption of the validity and adequacy of the voluntary conception.

II

Thus far we have merely observed the rejection of the concept of status responsibility in criminal law, as represented by the Supreme Court, and in morality, as articulated by H. L. A. Hart. But whether this concept has theoretical or practical advantages of its own has not been considered; nor has the conceptual or practical adequacy in law and morality of the prevailing concept of voluntary responsibility been critically assessed. So far we have accepted passively the view of the many that the concept of status responsibility-because it conflicts with the voluntary conception-is immoral and should be rejected. But Plato has warned us about the views of the many.

If we probe beneath the surface we shall discover, I think, (1) that moral and criminal offenses cannot be understood either as voluntary actions devoid of status or as states of being devoid of intentional activity; (2) that neither status nor voluntary responsibility is adequate in law or in ethics; that both are high abstractions defying sensible application in either field; (3) that human action, which cannot possi- 
bly be understood either as pure status (being) or pure voluntary intentionality (doing), is the complex, active being of living persons who function at various points on a continuum of action-a continuum that approaches vanishing points at the opposite extremes of pure being and pure doing; (4) that the continuum of human action is divisible into, or can be ordered in terms of, actions of distinctive types whose properties are functions of the proportion of status and voluntary elements; (5) that a sound concept of responsibility must be so fitted to the continuum of action over which it applies that it can designate the modes of response available to and/or obligatory for persons functioning at any particular point on that continuum.

Nothing less than an entire theory of human action and responsibility could establish all these points. In the rest of this paper I shall confine myself (a) to showing some of the perplexities that arise when one tries to understand certain moral experiences in terms either of the doctrine of the Supreme Court in Robinson v. California, or that of Hart; (b) to the partial analysis of Hart's paradigmatic statement of the character of moral offenses and moral obligation; and (c) to suggesting the value and power both for law and ethics of a concept of responsibility containing both status and voluntary elements.

\section{A.}

If we take a more careful and critical look at the work of the Supreme Court in Robinson v. California, we find apparent in the Court's decision the practical absurdity of trying to separate the being and the doing of human agents-an effort required by the distinction between status and voluntary responsibility. The Court agreed that the California statute under which Robinson was convicted would have been valid had it required proof of the actual use of narcotics within the state's jurisdiction. Yet if the Court was correct in defining narcotics addiction as a disease, and if one characteristic of this disease is the compulsive use of narcotics, it is difficult to understand how a statute inflicts a cruel and unusual punishment by holding one responsible for having the disease, whereas the punishment would not be cruel or unusual if it were applied to those acts which are the inevitable consequences of the disease. To use the example of the court, if "even one day in prison would be a cruel and unusual punishment for the 'crime' of having a common cold," why would the punishment be any less cruel or unusual if it were for the "crime" of having sneezed, coughed, or blown one's nose?

The Court was obviously on absurd ground philosophically when it 
tried to separate acts of addiction from the status of addiction. If the Court was right in holding that addiction implies use and that use is criminal, how could it deny that addiction is criminal? But if addiction is not criminal, then it would seem to follow logically either that addiction does not imply use or that use is not criminal. ${ }^{22}$

The Court could have avoided this absurdity by boldly asserting that because the status or condition of addiction and the use of narcotics are inseparable, the condition-and-use together are the disease, and that therefore neither the state of addiction nor the use of narcotics can be punished as a crime. ${ }^{23}$ The Court was reluctant to take this step for many reasons. Paramount among them is the fact that the Court would have had to blur the distinction between the condition or state of being of the accused and the actions of the accused. This blurring would, in turn, destroy the traditionally accepted "factual" basis for the distinction between voluntary and status responsibility.

The refusal of the Court to take this step is not entirely regrettable. There may be important uses for the fiction of pure actus reus and voluntary responsibility, despite their philosophical limitations. Indeed, it is one of the beauties of the law-sufficient perhaps to revive the lost faith in a Divine Order-that the Supreme Court can serve the interests of philosophers while making serious philosophical mistakes. However impossible it may be to separate the use of narcotics from the status of addiction, it is quite clear that we do not want the police arresting citizens in the absence of any antisocial behavior. Political liberty was served by the decision in Robinson, despite the fact that the decision reveals the artificiality and absurdity of sharply distinguishing action from being, or voluntary from status responsibility.

22 Mr. Justice Harlan, as previously observed in note 15 supra, avoided this pitfall in his concurring opinion.

23 This appears to be the direction taken by the circuit court in Driver v. Hinnant, 356 F.2d 761 (4th Cir. 1966). The court held that the constitutional provision against cruel and unusual punishment precluded North Carolina's punishing a chronic alcoholic for public drunkenness. In language reminiscent of Robinson $v$. California, the court said: "The upshot of our decision is that the State cannot stamp an unpretending chronic alcoholic as a criminal if his drunken public display is involuntary as the result of disease." $356 \mathrm{~F} .2 \mathrm{~d}$ at 765. "The alcoholic's presence is not his act, for he did not will it. It may be likened to the movements of an imbecile or a person in a delirium of a fever." Id. at 764. See also Easter v. District of Columbia, 361 F.2d 50 (D.C. Cir. 1966), in which the circuit court recognized chronic alcoholism as a defense to the charge of public intoxication.

Future developments may be presaged in the dissent of Mr. Justice Fortas to the Supreme Court's denial of certiorari in Budd v. California, 385 U.S. 909, 912-13 (1966): "Our morality does not permit us to punish for illness. We do not impose punishment for involuntary conduct, whether the lack of volition results from 'insanity;' addiction to narcotics, or from other illnesses. The use of the crude and formidable weapon of criminal punishment on the alcoholic is neither seemly nor sensible, neither purposeful nor civilized." 
B.

If we turn to an examination of the philosophical doctrine of voluntary responsibility as presented in Hart's paradigmatic statement, there are many points to be considered. One remarkable feature of Hart's characterization of moral offenses and moral responsibility is that he restricts himself to a pejorative context, to a context of moral failure. Hart's characterization of the distinctive features of morality in terms of moral offenses might be explained by the fact that the description is given in the context of a discussion of the similarities and differences of law and morality. There is very little in the rules of law or ethics concerning obligations to praise others or the right to claim praise for ourselves. The rules of law and morality derive their importance from the fact that they are so often transgressed; hence, most of the thought and ingenuity expended in these fields has of necessity been directed to the recognition, evaluation, and just handling of transgressions. We no more need to praise the morally virtuous than to pin medals on those who have kept out of jail. The norms of ethics and law define a high level of expectation. In law they are occasionally exceeded, but only in those moral systems providing for supererogation is there even a logical possibility of exceeding ethical norms.

But these considerations do not, in my opinion, account adequately for the negative character of Hart's exposition. Hart's selection of the pejorative context derives, I believe, both from his view of morality and from his idiosyncratic, if not dogmatic, linguistic restriction of the term "responsibility" to situations of failure.

Hart's view of morality is essentially rule oriented. He discusses moral offense only as action that offends against moral rules or principles. If the possibility of moral offense or moral achievement is restricted to the compliance with or transgression of moral rules or principles without regard to the fulfillment or loss of moral values, moral achievement will at best be the neutral absence of moral offense. In this particular context we cannot expect Hart to say everything about ethics, and perhaps he would wish to supplement his account of morality with a discussion of values. But recent English and American ethical thought has been so dominated by the discussion of rules and their many kinds that $I$ doubt it. This is rather a bias in contemporary English and American ethical discussion that needs correction by a channel crossing and an extended vacation on the Continent.

Hart's restriction of "responsibility" to contexts of failure would preclude, for example, our substitution of a context of moral achievement and compliance for his context of moral failure and offense, although there is nothing about the English language (or any other 
language) that prevents it. Suppose we use most of Hart's own words to describe an action which has not offended but has accorded perfectly with moral rules or principles. Consider the following:

If a person whose action, judged $a b$ extra, has been in complete accord with [has offended against] moral rules or principles, succeeds in establishing that he did this unintentionally and in spite of every precaution that it was possible for him to take, he is denied [excused from] moral responsibility, and to praise [blame] him in these circumstances would itself be considered morally objectionable. Moral praise [blame] is therefore excluded because he has had too little or nothing to do with it [done all that he could do].

We may continue:

[I]n morals "I didn't really do anything" ["I could not help $\left.\mathrm{it}^{\prime \prime}\right]$ is always a reasonable disclaimer [an excuse], and moral obligation would be altogether different from what it is if the moral achievement ["ought"] did not in this sense imply performance ["can"]. 24

Hart would surely object to the substitutions; he would never countenance my speaking of responsibility for a morally or legally exemplary act. Yet there is nothing odd about this usage. A morally good person would immediately object to being credited with responsibility for an apparently exemplary act which he performed either inadvertently or not at all; he might likewise feel some disappointment if another person were credited with responsibility for an exemplary act which he had in fact performed and for which he was in fact responsible. This is perfectly intelligible talk, and not unheard of. We also find the honorific use of "responsibility" in such statements as the following: "He is a thoroughly responsible person," or "he was responsible for saving the child's life," or "he deserves no credit since he was not responsible for it." There is nothing odd about these statements, but let us suppose there were. What has one proved if he establishes that a given usage is odd besides its oddness? Surely "odd" does not imply "wrong" or "mistaken." Nor could the fact of linguistic oddness, if it were a fact, offset the most important nonverbal fact about responsibility, namely, that personal involvement provides the basis for responsibility whether in contexts of success or failure. Hence we have the right to use the word "responsibility" when there is personal involvement whether it be praiseworthy or blameworthy. ${ }^{25}$

24 This is the same passage quoted at note 7 supra. Hart's original phrases are inserted in brackets following my italicized alterations.

25 The relevance of this discussion should be apparent in due course. If responsibility 
With these preliminary observations out of the way, let us now consider Hart's discussion of the voluntary character of moral offenses point by point, beginning with the first sentence:

If a person whose action, judged $a b$ extra, has offended against moral rules or principles, succeeds in establishing that he did this unintentionally and in spite of every precaution that it was possible for him to take, he is excused from moral responsibility ....

I find two ambiguities in this sentence which are not apparent or troublesome if one accepts dominant contemporary views about intention and action. For example, does "did this" refer to an action performed unintentionally by a person, or does Hart hold that all action involves intention? If he holds that in every action the agent must have an intention, it follows that "did this" cannot refer to an action but only to an event which, judged $a b$ extra, might have appeared to be an action. I assume that Hart accepts the dominant view that intention is an essential ingredient in action; hence that there could be no action which was not intended. But whether Hart takes the broad or the narrow view of action-i.e., whether "did this" refers to an action or merely to an event-is of no great importance in this context, because Hart clearly insists that moral offenses are voluntary and that actions or events (whichever word is appropriate) neither intended nor the result of negligence are not voluntary and therefore are excusable. Consequently the undetermined scope of the term "action" results only in an unimportant vagueness so far as this passage is concerned.

There is a vagueness or ambiguity in the word "intention," however, which is of critical importance. Does Hart restrict the meaning of intention to that which is consciously intended, or would he accept the view that there are subconscious, unconscious, and organic modes of intention in addition to the conscious modes in their varying degrees of focus and intensity? By means of an examination of this passage alone there is no way to determine which alternative Hart accepts. It can be seen, nevertheless, that these alternatives confront Hart as a dilemma: the consequences of either option are inimical to his position, and support the view of action and responsibility which $I$ wish to urge. If Hart accepts the narrow conception of intention, he must sacrifice factual support for his position; if he accepts the broader conception of intention, he must blur the distinction between volun-

is limited to pejorative contexts, it will be difficult if not impossible to present in ordinary English a continuum theory of responsibility in which voluntary and status elements are combined. The increased difficulty would be, moreover, the gratuitous consequence of linguistic dogmatism. 
tary and involuntary to the point that moral offenses cannot be accurately designated by their distinctive voluntary character.

If we take the latter alternative and recognize varying degrees and kinds of intentionality, we recognize our personal involvement to varying degrees in complex series of events. This recognition involves our acceptance of the sequence as our action even though we may not have fully or even consciously intended it. On this view, we preserve the essentially intentional ${ }^{26}$ character of all action while recognizing the degrees of action corresponding to the degrees and kinds of intentionality and personal involvement. This position, which I take, is more adequately supported by the few relevant facts available than the former alternative, which restricts intention to consciousness. But Hart cannot approve this latter alternative along with its factual support without destroying his thesis that moral offenses are essentially voluntary. For if we admit that personal involvement in action need not be accompanied by conscious intent in order for the action to be morally imputed to the person as agent, we destroy the basis for any sharp distinction between that which is and is not voluntary, thereby destroying the foundation for any sharp distinction between voluntary and status responsibility, and we alter radically the conditions or criteria of moral excusability. It is, then, clearly impossible to speak accurately or precisely of the essentially voluntary character of moral offenses. ${ }^{27}$

I presume, therefore, that Hart accepts the former alternative and restricts intention to that which is consciously intended. He holds, I believe, that a person succeeds in establishing that he did $X$ unintentionally, if he can show that he did not consciously intend to do $X$. But what justification can Hart offer for restricting the meaning of intention to conscious intention-for assuming, that is, that there is no such thing as subconscious or unconscious intention? Perhaps he would rely on Stuart Hampshire's argument that: "The sleeping and unconscious man is not an agent. ... It is a necessary truth that he has no intention under these conditions." 28 It would seem that Freud's demonstration of censorship in dreams and, indeed, the manifest con-

26 Here, of course, "intentional" has a common sense and not a phenomenological, technical meaning.

27 I shall consider later the question of whether the acceptance of this view alters the relation of implication between "ought" and "can" in such a way that, as Hart alleges, moral obligation would be transformed into something altogether different from what it is.

28 S. HaMpshire, Thought and Action 94 (1959). Consider also Hampshire's statement: "A more decisive difference between consciousness and unconsciousness lies between the necessity of intended action in the one case and the mere natural movement without intention in the other." Id. When done by linguistic fiat, as in this instance, philosophy becomes as easy as it is irrelevant. 
tent of dreams apart from any Freudian interpretation, force us to recognize the intentions of the dreamer; his personal involvement seems to color everything. Yet, like many American and English philosophers who ignore Kant's adage that concepts without percepts are empty, Hart perhaps assumes that the logic of language will supply our want of information. By restricting the meaning of intention to conscious intention and the meaning of voluntary action to that which is done intentionally, Hart can preserve the sharp distinction between voluntary and involuntary and, thereby, the basis for his insistence on the voluntary character of moral offenses. His theory gains clarity, precision, and some coherence by this move to linguistic rationalism, but it loses its factual support and plausibility.

I do not reject Hart and Hampshire's restriction of the meaning of intention to conscious intention on the basis of my intuition of the "logic" of the term "intention" or on the basis of my "right" to replace their definition with one of my own. I urge, rather, that there are relevant facts about human action which are denied when one insists that a person has to be conscious of what he intends in order to have an intention. Just as the anatomy and organic functions of the whale force us to admit that a whale is not a fish, regardless of the logic of the term "fish" or the definitions of venerable dictionaries, the anatomy and dynamics of human behavior and action force us to recognize unconscious and subconscious, no less than conscious, intentions.

Factual support for the broader conception of intention, and for the theoretical implications regarding responsibility that follow from it, is found in abundance in the daily affairs of ourselves, other individuals, and nations. How am I to regard those movements of mine which are judged by others, $a b$ extra, to be my actions and which may reveal to others one or more of my overriding, long range intentions, but which I can truthfully report were not a part of my conscious intention at the time my movements took place? Consider the way, for example, men and nations pick fights and exacerbate quarrels to their enormous advantage while truthfully and conscientiously denying all conscious intent or desire to fight. Consider Oedipus' attack on Creon; did he really believe that Creon was guilty or was this just the sort of conduct to which Oedipus was habituated? Consider Odysseus' trifling, yet possibly sincere, excuses for failing to support Hecuba in Euripides' play; what did he really intend? Consider the actions and intentions of Hitler and Chamberlain prior to the outbreak of World War II. In these cases we have factual proof of action possessing an intentional structure, or a goal-direction, radically at odds with its conscious intention. 
And such actions must be judged morally. We are prepared, I believe, to say that both Hitler and Chamberlain were morally blameworthy men, the one for his almost diabolical craving for universal destruction (however much he may have spoken of peace and German fulfillment $)^{29}$ and the other for his cowardice and preoccupation with immediate selfish advantage (however much he may have spoken of reasonable compromise in the interest of peace).$^{30}$ Are we not prepared to recognize, moreover, the corporate moral guilt of the Englishmen who cheered Chamberlain on his return from Munich and of the Americans who relied on Washington's Farewell Address to justify avoidance of entanglements on behalf of freedom in Europe? But did these Englishmen and Americans consciously intend to behave as cowards or to evade their moral obligations on the Continent?

More prosaically and perhaps more convincingly still, consider the Christmas dinner at which the spinster aunt, in the shrill voice of Carry Nation, delivers a temperance lecture while the father is opening a bottle of wine saved for the occasion. Are we to deny that the aunt's dislike of the father for having destroyed her only immediate family by marrying her sister, and the aunt's envy of her sister for being the mother in another family, are expressed in her action? Are we to believe that she does not desire and intend to hurt this family, to dampen the pleasures of its Christmas feast? Yet who would call the aunt a liar when later, in tears, she apologizes for having spoiled the celebration while she continues to insist that her only concern was for the welfare of the father and mother and children who are going to destroy their health by drinking? The aunt can claim, with complete justification, that her love for the family has been fully demonstrated by her generous and loving support in times of extreme hardship at great personal sacrifice to herself. But it is equally true that she is resentful of the family and full of hate. And since her actions are hers, it is not surprising that they should reveal much more of herself than she consciously intends to express: what she does is a function of all that she is, all her loves, hates, and wants, and not merely the expression of what she consciously intends when she acts. In this case all of her action, including its disruptive consequences and its good and bad will, was intended and was done intentionally, despite the fact that her conscious intention was merely to save the family she loved from

29 Mircea Eliade lays great stress on the National Socialists' selection of the Nordic myths as an expression of national purpose: the goal is ragnarök-total destruction of gods, heroes, and men! M. EliAde, Mirthe, Dreams AND MYsteries 26-27 (1957).

30 When Chamberlain said that he brought back from Munich "Peace for our time," he let the cat out of the bag. It is not hard to find the intent behind that phrase or behind the equally famous "Après nous le déluge." 
alcoholism. The most accurate account of this situation is one which simply accepts as fact the presence of unconscious and often ambivalent intentions.

Five years ago in Austin, Texas, a man charged with the murder of his wife claimed in his defense that he had killed her while sleeping or immediately on awakening. ${ }^{31}$ Psychologists and psychiatrists testified to the possibility of this occurrence. And if the man had lived happily with his wife for twenty years, one might be inclined to excuse his act on the grounds that it was unintentional. According to the evidence, however, the man and his wife fought frequently, and he had planned on two occasions to divorce his wife in order to marry another woman. By his own admission he dreamed that he was killing an intruder who was chasing his nieces before awakening to find that he had killed his wife. I would accept as factual that the man killed his wife while in an unconscious or subconscious state. But I see no reason for concluding, as Hart or Hampshire would, that the man did what he did unintentionally and, consequently, that he is to be excused from moral blame for killing his wife. (Nor would I argue, on the other hand, that he should be found guilty or punished in a court of law on the basis of these facts unless and until careful safeguards and limitations have been developed for the introduction of such evidence. I fully recognize that the implementation of my theory in legal practice requires the development of solutions to a host of special problems. Neither the problems nor their solutions can be dealt with here.)

Hart insists that a person is to be excused from moral blame if he can establish "that he did this unintentionally and in spite of every precaution it was possible for him to take." Now if we admit that the man killed his wife while in a non-conscious state and that consciousness is required for intention, it follows that in this case the man did what he did unintentionally. And unless we consider him reckless or negligent for having continued to sleep in the same bed with his wife after having quarrelled with her, ${ }^{32}$ we have no basis for claiming that he failed to take every precaution it was possible for him to take. We cannot fault him for having failed to consult a psychiatrist or marriage counsellor; recourse to such professional help presupposes a level of education and sophistication which the accused had not attained. ${ }^{33}$ On Hart's view, we must conclude, therefore, that the man was neither

31 State v. Blomquist, No. 33391 (D. Tex., May 17, 1962).

32 Survival of the institution of marriage would require the negligence of most of the aduit population if such a consideration were made a rule of law.

33 We will discuss later the problem of accounting for negligent conduct on a theory which recognizes only a conscious level of intention and awareness. See Marshall, Relation of the Unconscious to Intention, 52 VA. L. REV. 1256 (1966). 
negligent nor intentional in his behavior, hence that he did not offend voluntarily, hence that he is excused from moral responsibility and blame. ${ }^{34}$ This, in my opinion, constitutes a reductio ad absurdum of the view that limits ascription of moral blame and responsibility to voluntary, consciously intended acts, the view that moral offenses must be voluntary and that in order to be voluntary they must be consciously intended.

There are at least two ways of avoiding this absurdity and acknowledging the moral responsibility of the agent in this case. First, we may hold that, since the man had no conscious intention to kill his wife, his bodily movements in killing her do not constitute an action, and hence that killing her was not voluntary. In this way we preserve the usages of Hart and Hampshire. But then we are forced to abandon Hart's thesis that moral offenses are voluntary: we are forced to predicate the man's responsibility on his being, or status, rather than on his voluntary action. We now avoid the absurdity of excusing him by morally blaming him for being a man who killed his wife even though he did not kill her voluntarily or intentionally.

Or, second, we may describe what the man did in terms of action, intention, and volition developed on a continuum view of responsibility. We may hold that there was a degree of voluntariness in his action proportionate to the degree and kind of intentionality and, consequently, a corresponding degree of moral blame. We would have to assess the degree and quality of his intention by reference to what he had thought, said, dreamed, and done about his. wife in the preceding months and years. And to the degree that the man's intentions, as so assessed, were apparent in his bodily movements of killing her, we would describe those movements as, to that degree, his voluntary action. ${ }^{35}$ This second way, by far the soundest in my judgment, provides a better fit of facts to theory than the first way. It imposes, moreover, very little strain on traditional linguistic usage and offers qualified support for the traditional view, represented by $\mathrm{Hart}^{36}$ of the voluntary character of moral offenses.

34 Hart would not necessarily excuse him from legal responsibility. Hart would not accept without serious qualifications Jerome Hall's position that "Penal law implies moral culpability." J. Hall, General Principles of Criminal Law 347 (2d ed. 1960).

35 Here $\mathrm{I}$ am making a theoretical point about law and morals. Practically speaking, it will be difficult, perhaps impossible, to prove "beyond reasonable doubt" what a man has thought or dreamed. Some move might nonetheless be made in this direction. It must be emphasized, moreover, that the introduction of such considerations might be made for the purpose of exonerating a person or for mitigating his guilt. It would be a serious mistake to suppose that the view I am developing tends more to incriminate than to exonerate mankind. My argument does not increase one's moral and legal responsibility; rather, it attempts to redefine and clarify the nature and scope of responsibility.

36 I have indicated at several points in this paper that Hart's statement represents, or is 
On the second view we recognize that there must be some element of intention and some degree of voluntariness in a series of bodily movements if those movements are to be called an action and if the action is to be subject to moral judgment. At the same time, moreover, we recognize the essential co-presence of elements of status responsibility. The mixture of kinds of responsibility reflects with accuracy the mixture of being and doing in personal action. It reflects the fact that what a man does is a function of what he, in the context of his situation, is, and that what he is within this context is revealed by what he does. The partial truth of the voluntary conception of responsibility is acknowledged through the recognition that what a man does is the ratio cognoscendi of what he is, and the partial truth of the status conception of responsibility is acknowledged through the recognition that what a man in context is is the ratio essendi of what he does. This view can also accommodate the existential point that what a man is and does determines or creates what he shall be and do; that his existence can give rise to a new essence.

We are compelled then, largely by factual considerations, to reject the view that intentions are necessarily or always consciously intended, that a person must be conscious of his intention in order to act intentionally. We are forced, that is, to reject the view that a person can establish that he acted unintentionally if he can show that he did not consciously intend to do what he did. And when the concept of intention is extended, the character of moral offenses and the criteria of moral excusability are altered; we recognize, for example, the possibility of being morally blameworthy for what we do on the basis of unconscious or subconscious intentions in the absence of any conscious intention to violate moral rules or principles or to neglect any values that should be enhanced.

And we have taken only the first step toward confronting factually and acknowledging theoretically the larger range, scope, and depth of mental concepts. The enlargement of the concept of intention must be accompanied by a comparable enlargement of the concept of awareness. The importance of this step can be seen most clearly in the present context if we ask whether a person can be morally blameworthy for negligent conduct. Hart recognizes, of course, the difference between intentional or purposive action and action which is done with knowledge or conscious awareness but without intent. $\mathrm{He}$ insists that the person whose action violates some moral rule or principle must, in order to excuse his 
conduct, establish not merely that he acted unintentionally, but also that he did not know that he was running any avoidable risk of violating them. He must establish that, in Hart's words: "[H]e did this . . . in spite of every precaution that it was possible for him to take." Thus, in order to be excused morally, the person is required to prove that his conduct was not reckless. But on Hart's view a person is not required to show that his action was non-negligent, for negligence, unlike recklessness, does not involve any state of awareness:

It is the case where the actor creates inadvertently a risk of which he ought to be aware, considering its nature and degree, the nature and purpose of his conduct and the care that would be exercised by a reasonable person in his situation. ${ }^{37}$

If Hart takes a narrow view of mind, intention, and awareness, and if he holds that moral offenses must be voluntary-by which he means that they must be avoidable by means available to the agent at the time he acts-how can the agent be blameworthy for failing to take a precaution of which he was not aware and which was therefore not available to him at the time he acted? If the agent is aware of reasonable precautions which he is neglecting to take, he is acting recklessly. But if he is not aware of any reasonable precautions that he is neglecting to take, in what sense can it be possible for him to take them? In what sense can he be voluntarily negligent and therefore morally blameworthy for his negligence?

It makes no sense to include among possible precautions that one ought to take precautions of which one is not consciously aware unless it is recognized that there are various modes of awareness, including peripheral, subconscious and unconscious modes, and that there are purposive acts of forgetting, repressing, neglecting, etc. If we accept the fact that persons express through their actions intentions of which they are not fully or even partially conscious, and if we give credence to the psychoanalytic and psychological evidence of repression and other forms of subconscious or unconscious awareness and activity, then-but only then-have we a sound factual basis for extending the concept of moral blameworthiness to truly negligent behavior. For it is only after we accept this evidence as factual that we have a basis for identifying the presence and effects of the person in such conduct. It is another shortcoming of the traditional view that moral offenses must be voluntary in the sense that they must be avoidable by means of which the agent is aware, that it limits moral blame to actions which are either intentional

37 Model Penal. Code \& 2.02, Comment at 126 (Tent. Draft No. 4, 1955). 
or consciously reckless and, hence, that it cannot impute moral blameworthiness (or praiseworthiness) for truly negligent conduct. ${ }^{38}$

On the basis of the extended view of awareness and intentionality, by contrast, it is possible to hold a person morally blameworthy and legally culpable for genuinely negligent conduct. And by the extension of the meanings of these mental concepts-in response to factual evidence, be it noted, and not to the "logic" or usage of these terms-we need not abandon but only qualify the traditional requirements that morally blameworthy acts be voluntary and that legally culpable conduct involve mens rea. ${ }^{39}$ In holding a person morally blameworthy or legally culpable for truly negligent behavior we recognize the presence of the person existing and functioning mentally on some level in the process of acting. We recognize degrees of moral blameworthiness or legal culpability appropriate to the degree and kind of personal presence in the action. The greater the degree of consciousness in awareness and intention, the greater the degree of voluntariness and mens rea; hence the greater the degree of moral and legal responsibility. ${ }^{40}$ Once again we confront increasing or decreasing continua of awareness, intention, mens rea, etc., on which our judgments—on continua scales-of the presence and degree of personality, voluntariness, action, responsibility, blameworthiness and culpability are based.

Because there is still much doubt (a good deal of which may be fully merited) about the soundness and relevance of data provided by depth psychology and psychoanalysis, I do not want to rest my case against the traditional, simplistic concept of voluntary responsibility exclusively or even primarily on such data. By restricting ourselves to familiar

88 In my consideration of the case in which the Texas man killed his wife, State v. Blomquist, No. 33391 (D. Tex., May 17, 1962), I dealt superficially with the question of his possible "recklessness or negligence" because $I$ had not yet introduced the technical distinction between negligence and recklessness. In retrospect it should be clear that the theory as represented by Hart is reduced to an absurdity when applied to this case because the man's conduct was morally excusable since it was, in terms of the theory, neither intentional, negligent, nor reckless.

80 Professor Herbert Packer, supra note 4, has urged the consideration of negligence as a conceptual halfway house between strict liability and mens rea. If we accept as factual a side of mental life of which we are not directly conscious but which, according to many psychologists and psychoanalysts, accounts for slips of the tongue, deliberate forgetting, and other failures that can be grouped under the general heading of negligent behavior, a substantial element of the mens rea requirement could be reintroduced into criminal and tort law under rules concerning negligence at points where at present rules of strict liability are used or where negligence is treated as if it were devoid entirely of mens rea and hence where rules of negligence are applied exactly as rules of strict liability.

$10 \mathrm{~A}$ continuum theory of human conduct and responsibility may have been behind and is certainly required by the A.L.I. proposal of four modes of culpability, which in descending order are: purpose, knowledge, recklessness, and negligence. See MODEL PENAL CODE $\& 2$ (Tent. Draft No. 4, 1955). 
experiences in daily life-without appeal to psychoanalytic interpretation-we can expose the inadequacy of the view that a person can excuse himself for morally offensive conduct by showing that he did what he did unintentionally and after taking every possible precaution. According to Hart's statement, if a person meets these criteria: "Moral blame is therefore excluded because he has done all that he can do... [and] in morals 'I could not help it' is always an excuse." But we can show, I think, that "I could not help it" is not always an excuse because moral responsibility can have no meaning in human affairs unless there are times and situations in which one is morally responsible (deserving of moral praise or blame) for what he is, whether he could have helped being what he is or not. That is to say, I wish to show by reference to uncontested facts of human experience that the concept of moral responsibility (and, by limitation, moral offense) involves some minimal element of status responsibility and cannot be based solely on voluntary responsibility. To show this at least sketchily will be the burden of the final part of this paper.

\section{III}

It is often mistakenly assumed in philosophical discussions of action, intention, person, and responsibility that everyone is clear about the precise, and even logical, difference between an event and an action, between an action and its consequences, between a voluntary and an involuntary action or movement, between a person and a thing. In fact, however, there is great uncertainty and fuzziness on all these matters: wherever we look we seem to find one item or concept fading by imperceptible degrees into another from which it is alleged to be factually or even logically distinct.

\section{A.}

We find for example, not merely the gradations of personality, agency, and responsibility in the sequential observation of comatose, vegetative, senile, idiotic, infantile, stupid, sleeping, insane, neurotic, normal, wakeful, rational, articulate, intelligent or imaginative persons, we also find a spectrum of action, personality and responsibility in the daily life of any ordinary human being. Consider the following experiences of $X$ :

1. While walking aimlessly in his garden, he steps on a thorn and feels a terribly sharp pain.

2. While playing badminton in his garden, he steps on a thorn and feels some pain. 
3. While in a desperate struggle with an intruder in his garden, he steps on a thorn and feels no pain at all.

4. While asleep he dreams of a stranger who is killed and whose estate is inherited by his brother.

5. Working in his garden while hungry he thinks suddenly of eating bacon and eggs.

6. Working in his garden he thinks of his brother who is on military duty in the war zone, and he offers silent prayer for his safety. In the midst of the prayer the thought crosses his mind that if his brother is killed, he will inherit his brother's estate.

7. Hungry but still at work in his garden, he decides to cook those eggs and bacon.

8. As he is going inside, he thinks, "I don't want my brother dead; what a scoundrel I must be for having a thought like that."

9. He prepares Iunch.

10. His brother comes in unexpectedly on a military leave granted so that he can recuperate from a wound and lead poisoning; $X$ invites his brother to eat with him.

11. X decides to slip a fatal dose of powdered lead into the eggs before serving his brother.

12. $X$ puts the poison in the eggs.

13. He serves the eggs to his brother.

Here we have a continuum of situations from events to moral action in which a gradual increase of personal involvement and responsibility is shown. At what point shall we speak of action rather than mere event? At what point does the personality of $X$ express itself in what happens or in what is done? At what point do we speak properly of moral responsibility or moral blameworthiness? Of legal responsibility or culpability? ${ }^{41}$

$X$ 's personality and personal involvement are apparent from the outset. Even the way in which $X$ feels pain in No. 1 has elements of action about it. The intensity of his pain is a function, presumably, of his degree of abstraction while walking, and of his normal pain threshold. If he has a low threshold and vivid memory of such experiences, the pain may be excruciating and he may relive the shock for hours or days. If his threshold is high a single "Dammit!" and the removal of the thorn may be all there is to it. Now are we to suppose,

\$1 My discussion of these thirteen situations will of necessity be very brief and sketchy; nevertheless, it should serve to carry the reader on his own through many of the considerations which I find relevant. 
in the interest of precision or clarity, that $X$ 's reaction to stepping on a thorn is just a reaction, a psychophysical event in which there is no personal involvement and no element of action? Can we doubt that $X$ 's response will be not merely indicative but largely determinative of his action in a situation of moral crisis in which the threat of pain is involved? If, while later serving in the army, $X$ were taken prisoner, how would he respond to the mere threat of physical torture? Can we assess his moral responsibility by asking, "Could he help doing whatever he does?" If his pain threshold is low and his memory of past pains and his imagination of pains to come are vivid, can he help divulging secrets on the mere threat of torture, whereas he would not divulge them even after torture, were his pain threshold high and his imagination and memory less vivid? Does it make any more sense to say "He could not help doing what he did" than to say "He could have avoided being who he was"? Or does it make any more sense to say "He could have avoided doing what he did" than to say "He could have avoided being who he was"? If what a man does is not a function of what he is, in what sense can his action be his? But if what a man does is a function of what he is, such questions make no sense. The proper question for the assessment of moral responsibility should rather be: "What kind of person is he-that is, under what conditions, both external and internal, does he do or would he do what he did?" I see no way of determining whether or not $X$ can be different from what he is or could be different from what he was at any particular time. Likewise, I see no way to determine whether he can do differently from what he does or could do differently from what he did at any particular time. But there are ways to determine to some extent the conditions under which $X$ does what he does and is likely to do what he will do-that is, we can come to know something about his character, including his moral character, and a statement of his character is a description of his being-doing.

Now if $X$ screams and cries when he steps on the thorn in No. 1, we may be able to talk to him about his behavior and train him so that he will exercise greater control on the next occurrence. When on the next occurrence he shows greater control, stiff upper lip, etc., are we to say that praise is inappropriate for it is only another event and not an action for which $X$ can be praised? Hardly. The fact is that we train children to exercise control-and hence to act to a minimal degree-even in the way that they experience pain. I can hear a critic saying: "But you train the child to control his response to the pain, not to alter his experience of it." It is probable that control would be impossible in cases of intense pain if there were no way of altering 
the experience itself. The unity of mind-body in human experience has been seriously underestimated by philosophers since Descartes. They have also underestimated or ignored the personal controis that we know are operative, but which we are not aware of as operating in such basic processes as perception.

But if one questions the presence of minimal personal involvement and therefore a minimal element of action in No. 1 , what will one say about No. 2 or No. 3 ? If we argue that the adjustments in the awareness of pain made in No. 2 and No. 3 are merely bodily adjustments having nothing to do with the person involved, we shall be left with a high abstraction instead of a richly concrete person. The extent of the reduction in the awareness of pain in No. 2 is not merely a function of the attention areas in the brain; it is likewise a function of $X$ 's involvement in the game. If he doesn't like the game, the pain is likely to be far more intense than if he were extremely fond of it. The greater his competitive involvement, the less intense the pain. If he is playing with a young woman in whom he has a strong romantic interest, his pain may be either lessened or intensified according to his courting technique, quite apart from the question of whether he will feign greater or lesser pain for courtship purposes. His personality will express itself instantaneously in the midst of play prior to his conscious assertion of secondary control. I see no reason to deny that the initial response is his personal response, not merely an organic reaction, though I should not want to deny the greater element of personal involvement expressed through his secondary control.

I acknowledge that pain must not be too intense if the element of personal action is to be found in the very perception of it. Pain so intense as to produce almost instantaneous loss of consciousness is clearly of a different sort. But this consideration should not blind us to the minimal expression of the person in the experience of less severe pains.

In a situation like No. 3 we should condemn a soldier or an athlete who did not suppress virtually all awareness of pain. (I introduce athletes into a situation like No. 3 out of consideration of American professional football which is much more like No. 3 than No. 2.) If he continued to feel pain from a thorn to the point that it interfered with his fighting, we should probably deny that "He did all that he could to control the pain." (Note we do speak of controlling pain when we can mean nothing other than controlling the way we experience it rather than the response we make to it.) We should be inclined, I think, to say that a football player who felt enough pain from a thorn in the foot to be seriously distracted by it while engaged in "hand to 
hand combat" cared too little about winning the game and "had not done all he could do" to win it. Whether or not we regard his failure as morally blameworthy depends on how seriously we take the game and whether we view it as a moral struggle, but not on the character of his action. His personal involvement, minimal though it be, is sufficient to justify imputation of some very small degree of moral blame.

By the time we come to situation No. 4, I should suppose the presence of personal involvement and responsibility would be generally acknowledged. It was Plato, not Freud, who first stressed the moral significance of dreams and who insisted that it was important to consider a person's dreams when assessing his moral character. It is universally acknowledged that dreams reveal the desires of the dreamer: starving men dream of sumptuous meals; sexually deprived persons dream of sexually pleasing objects; bed-wetting children dream of toilets while they wet their beds. Now if we add to these commonplace observations Freud's theory of dream censorship, we find an important similarity between No. 4 and No. 6 . Freud would morally credit $X$ for his dream work, for his censorship of his dream. He would assert that $X$ 's love or respect for his brother, or at least his acknowledgement of his brother's right to live, was expressed in his suppression of the true content of his dream and in his provision of the manifest content. Freud would say that $X$ was a better man for dreaming what he dreamed in No. 4 than if he had dreamed directly of his brother's death, for his dream in No. 4 shows that he disapproved of his own desire. ${ }^{42}$ Without trading on the metaphysics of psychoanalysis, I should argue that $X$ 's incompatible wants were revealed in No. 4: his affection for his brother is in conflict with his desire for his brother's estate. And I should argue that we can never make sense of personal or moral responsibility unless we recognize the expression of the person and hence a mode of personal action, if not in one's dreams, at least in one's wants and desires.

By moving from No. 4 to No. 5 we confront essentially the same issues but in a context in which the rejection of Freud's or Plato's interpretation of dreams poses no threat to my position. But I do not wish to deny what seems to me the clear moral relevance of dream behavior. I contend that no one would knowingly hire a baby sitter who frequently dreamed of killing kittens or chickens, much less one who dreamed frequently of killing children. We all know perfectly well that our dreams reveal ourselves, our persons. When I was a child of eight 
-and long before I had heard of Freud-I dreamed on two occasions of the deaths of my parents. In these dreams I basked in the emotional glory of being the "poor little orphan." When I awoke I was ashamed of myself for indulging in those gratifying thoughts of having everyone sorry for me at the cost of losing my parents. I considered then, and now consider that a moral fault (admittedly of trivial importance) was revealed in those dreams. But I would not know what it means to be me or what my moral quality as a person were unless I based my judgment on all indices of myself. I might add that in dreams in which I have "done the right thing" in a situation of great temptation I have awakened mildly pleased with myself. Only a fool would ignore what he can learn of himself through his personal activity in dreams.

For the sake of those who reject Joseph along with Plato and Freud, however, there are always No. 5 and No. 6. If in a fully conscious state I think of the attractive consequences of my brother's death in a situation in which I am concerned for his well-being (I need not be praying about it), I must obviously recognize my ambivalence toward him. And if I have no basis for wishing him ill, must I not recognize my personal involvement and agency in the morally blameworthy thought of the attractive consequences of his death? Let me emphasize once more that we are speaking here of microscopic blame. $X$ could not be called a basically morally bad person because he had the dream in No. 4 or the thought in No. 6 unless they were interpreted later in light of Nos. 11, 12, or 13. But the continuum of personal activity and responsibility is what I wish to stress. And I think we find in No. 6 a significant though minuscule instance of personal agency, responsibility and, indeed, moral blameworthiness. The degree is far greater, moreover, than in situations No. 1 through No. 5.

Situations No. 4 through No. 6 show that a person's wants are a part of him and an expression of his personal agency. A man who will not assume responsibility for his desires and wants may just as well deny responsibility for his mind-body. I believe that what I say accords with the findings of clinical psychology insofar as the person who does not recognize himself in his desires and wants and in the subtle ways in which their intensity bespeaks his control of them, antecedent to consciously deliberate control, is suffering some degree of mental illness. (Ego is no longer master; repression is terribly extended, etc.)

In situations No. 1 through No. 6 we have the gradual emergence of clearly recognizable action from events in which faint but significant traces of personal activity are found. In situations No. 6 through No. 13 we have actions in which there is a gradual development of conscious deliberation and moral responsibility. Numbers 11 through 
13 can be described as one action or as three, but the quality of the decision in No. 11 is not fully revealed until the occurrence of No. 13. $X$ 's decision in No. 11 may not have been fully determinate even in the mind of $X$ at the time it was made. His decisiveness becomes complete as his action develops. But even at No. 13 there may be irresolution: No. 13 may be followed by a No. 14 in which $X$ snatches the plate away before his brother can eat. The person of $X$ may change and develop in the tension of the situations. But his being will never be separated from his doing; he is and does together and at once. It makes no sense at any point to say that he could have done differently unless he could have been different.

Of course there were alternatives open to $X$ at every point from No. 1 through No. 13 and, as we noted, alternates remain open after No. 13. But were there alternatives which $X$ could have taken while being what he was at each instance? This is the question we cannot answer with any empirical guarantees. Only the metaphysicians of free will or determinism can fight this issue through. But we can recognize the important differences in the quality or kind of alternatives available to $X$. We note that his awareness and conscious deliberations are on an increase from No. 1 through No. 13. His alternative at No. 1 may be little more than the possibility of accepting or rejecting himself as the person he is and deciding on a course of training to raise his pain threshold. Indeed in all situations from No. 1 through No. 5 his action or activity is not so much planned as happening. And his act of praying in No. 6 is a sudden impulse (though a morally significant and revealing one). But in No. 7 there is planning. He decides on a course of action-which is itself an action or part of one - before he goes inside or gathers the food and the utensils and begins to cook. Time passes between the action of No. 7 and the cooking of the eggs. And in every moment of time there are occasions in which his person can express itself in different ways if his person is such that the expression comes forth. But time, the sine qua non for alteration of plans, for the expression of ambivalence or contrary desires or intentions, for deliberation and thoughtful consideration, is provided. And the person whose action has been undertaken and sustained through prolonged moments of time, in which deliberation and consideration of alternative desires, wants, intentions and plans may express themselves through the alteration of the course of that action, is more fully identified and identifiable with that action than a person whose action is of less duration down to the point of being almost instantaneous. Enduring action in which the full capacities of the person are engaged is what is properly meant by voluntary action: 
it is expressive of the volition of the person; it reveals what the personal agent wants to come to pass in the world and what he wants to be.

Concerning voluntary action, we can say that there was time and opportunity for the agent to do differently from what he did had he been a different person from what he was. Hence we are prepared to blame him more for such action, because his personal identification with and in such action is greater. In blaming him severely only for voluntary actions, however, we are not denying that we are blaming him for what he is as well as for what he does. We blame him more severely because his fully conscious mind and deliberative choice are expressed in temporally extended voluntary action. We blame him less severely for impulsive or responsive actions or for dream actions precisely because far less of himself is expressed in or identified with them.

\section{B.}

In section A we examined an event-action continuum in which we observed the gradual increment of personal expression as we moved from cases of predominantly event-like reaction, through those involving sudden responses, dream work, impulsive thoughts or desires, to cases of maximally conscious, voluntary and deliberative action. The continuum was one of increasing personal involvement and expression, increasing voluntariness, and increasing responsibility. Throughout we found, moreover, the co-presence of personal being and personal doing, and we observed the artificiality that results from the separation of the person's being from his doing.

In section $A$ we observed and considered only a small aspect of the ontological foundation of action and responsibility. Action and responsibility depend on far more than the being and doing of the agent himself; they depend also on the being and doing of other agents and finally upon the general matrix of action, including all of the ontological conditions on which action depends. The ontological matrix of action no less than the intentions of the agent sets the determinate limits of action and the degrees and quality of responsibility.

Let us resume our consideration of $X$ by supposing that each of the following situations is an alternative successor to No. 13:

14. $X$ snatches away the eggs just before his brother eats them.

15. $X$ 's brother begins to eat, feels sick almost at once and stops eating before consuming a fatal amount; $X$ throws away the 
eggs a) in happy relief that the plan has failed, or b) in anger that his plan has failed.

16. X's brother eats the fatal meal and dies.

17. After serving the poisoned eggs, $X$ leaves the house for a few minutes; while he is gone his mother enters, partakes of the poisoned meal, and a) both she and the brother die, or b) the brother feels sick, does not eat, and only the mother dies.

In No. $14, X$ is still in control as much as any voluntary agent is in control of his action; that is, his action has not yet set in motion or been caught up by forces that may result in a disrelation between his action and his plan or intention. In No. 14 we see that the determination, expressed with increasing clarity and force from No. 11 through No. 13 is still far from steadfast or overpowering. In No. 14 we find that determination is shaken by competing aspects of $X$ 's personality and interests; his action now expresses perhaps either his prudential concern for his own safety and well-being, his continuing but ambiv. alent love for his brother, or his respect for law. $X$ 's movement in No. 13 may have been impulsive: an expression on his brother's face may have reminded $X$ of a happy incident from their childhood. Alternatively, his movement may have been deliberate: he may have known, even as he was serving the plate and carrying it to the table, that he would have to snatch it away at the last; perhaps he only toyed with the idea of murder and even savored the moral test he was putting himself through. The range of possibilities is almost infinite.

But No. 14, whether impulsive or deliberate, forces us to reassess $X$ 's blame. Our judgment made on the basis of No. 11 through No. 13 is no longer adequate. If $X$ 's action from No. 11 through No. 13 was deliberate while his action in No. 14 was impulsive, can we allow our judgment based on No. 11 through No. 13 to stand? Shall we argue that No. 11 through No. 13 prove that he intended to murder his brother and that it is immaterial that he was stopped by an expression on his brother's face rather than, as in No. 15, by the fact that his brother does not eat the poisoned food? Shall we argue that he was stopped in either case by an accident insofar as he was concerned? We must argue, I think, that he is to be credited morally for his response to his brother's expression in a way that he is not to be credited for his brother's refusal to eat the food-though both accidents, if that is what they are, partially determine his moral worth. Much of $X$ is centrally involved in his response to his brother's facial expression: it is not just the expression but the expression as seen by $X$ that accounts for $X$ 's throwing away the eggs. The expression as seen by $X$ shatters 
his resolution and alters his intention, whereas there is no break in $X$ 's intention in No. $15 \mathrm{~b}$. We must give $X$ moral credit for his response to his brother's expression, or for his deliberate consideration in which his love for his brother was reasserted, or for his thought of his brother's right to live and the wrongness of murder, no matter how intensely he may have hated his brother.

We must give $X$ moral credit, though to a lesser extent, even if his action in No. 14 expresses nothing more than his prudent concern for his own safety; there is an important element of moral goodness in the man who is law-abiding even for the wrong reasons-he does not destroy some of the values that the laws protect. Or are we so carried away by the moral daredeviltry of formalistic, voluntaristic ethics that we find no moral worth in law-abiding conduct which is prompted by selfish motives?

The situation in No. 15 seems radically different from No. 14, but it is only gradationally different. In No. 15 the action has clearly moved beyond the voluntary control of $X$. But did $X$ have voluntary control over his brother's expression in No. 14, or over the present strength of his love for his brother, or over the education that developed whatever sense of duty and respect for the lives of others that may have moved him in No. 14 ? We know what $X$ was in No. 14, but we must not slip back into the mistake of supposing that $X$ could have done differently in No. 14 any more than in No. 15 without having been a different man in these situations.

Since the situation in No. 15 is nonetheless beyond the voluntary control of $X$, what should we conclude concerning his responsibility? His maximally voluntary responsibility must be assessed by reference to his reaction to the failure of his plan-to the truncation of his action. In $15 \mathrm{~b}$ we find that his resolution was complete: $X$ did his best to kill his brother and never wavered in his intention. We can say, as I suggested in another paper, ${ }^{43}$ that $X$ murdered unsuccessfully. But that is a misleading way of putting it, for it is a brute fact that in No. 15, $\mathrm{X}$ did not murder his brother. The continued existence of his brother provides an ontological refutation of any charge of murder. $X$ has been saved by his brother's sensitive digestive system from the crime of murder. Although $X$ did all he could to bring it about, although his voluntary involvement was complete, his action was terminated short of its completion. His action was defined by his intention to kill his brother, but his action was terminated a) after he had done all that he could to realize his intention but b) before his action had

43 See Silber, Human Action and the Language of Volitions, 44 Proceedings of the ARISTOTELIAN SOCIETY 199 (1964). 
been completed by his brother's death. In $15 \mathrm{~b}$ we have a situation in which the ontological matrix of the action does not support the volitional matrix, and the discrepancy is effectively articulated, in my opinion, by the traditional language of volition. $X$ willed to kill his brother and is morally blameworthy for his acts of volition even though he did not succeed.

But is $X$ as morally blameworthy for having willed, but failed, to kill his brother, as he would have been if his action had fit his intention; if, that is, his volitional act had been completed by his brother's death? ${ }^{44}$ Unless we banish from ethics all concern for the realization of values, our answer must be that $X$ is not so blameworthy. In spite of his volition $X$ is not guilty in No. 15 of having destroyed a human life with all its values! If in No. $16 X$ can be held responsible morally for his brother's action in eating the eggs and for the action of the poison within his brother's system, why should he not be relieved of some responsibility and blame if these intended and probable consequences of his efforts in preparing and serving the eggs do not take place?

The traditional answer has been that $X$ intended the consequences and did everything in his power to bring them about; hence, they are a part of his action and he is morally accountable for them whether they happened or not. Persuasive as this answer is, it overstates the case. It ignores the absence of certain elements of being or status requisite to full moral responsibility. The man who has attempted murder, as $X$ has in No. $15 \mathrm{~b}$, is as guilty volitionally as he can possibly be. But he lacks the being or status of a murderer. It would be a reductio ad absurdum of the theory of voluntary responsibility to assume that he would not be far more blameworthy had he acted in an ontological matrix that supported his intent and brought about its full realization. On the other hand, it would be a reductio ad $a b$ surdum of the theory of status responsibility to assume that the man who has attempted but failed to commit murder has no moral guilt as a murderer just because his victim is still alive and unharmed. His volitional offense still stands.

Much more needs to be said about the ontological matrix of action.

44 We raise this question while recognizing that to will something, unlike merely to wish it, involves a determined effort on the part of the agent; within the limits of his capacities, the agent does everything he thinks is required for the fulfillment of his intention. If one wills something to happen, its failure to come to pass cannot be imputed to the volition of the agent for if he wills it he does what he can to bring it about and does nothing to prevent it. I do not accept any para-mechanical theory of the relation of mind to body or any of the other horrible things that Ryle alleges are accepted by those who use the language of volitions. See $i d$. 
But it is already clear that it can alter the agent's action despite his intention or volition and, hence, that it can alter his moral and legal responsibility. If we limit our considerations merely to $X$ 's awareness of himself and ignore what the law or his family might think of him we must recognize the difference in what he as a person is in No. 15 (whether a or b), and what he is in No. 16. According to No. 15, $X$ is not a murderer although he has a murderous will in No. 15b and may have no better than an ambivalently murderous will in No. 15a. In both Nos. 15a and 15b, however, there are redemptive possibilities open to $X$ that are closed by No. 16. Reconciliation with his brother is only the most obvious. By considering the difference between $X$ in No. 15 and $X$ in No. 16 we see plainly his finitude both physically and morally: he is dependent with regard to both his moral guilt and virtue on many ontological factors that are not under his control, not even in the weakened sense of being expressions of his volitional being. This fact of the dependency of his moral virtue or guilt on ontological factors beyond his control is not acknowledged by the traditional view of moral responsibility according to which one deserves credit or blame only for what he has done voluntarily. The traditional view necessarily ignores this fact because it has ignored the ontological foundations of voluntary action.

In No. $15 \mathrm{a}$ we have a situation that is similar in many respects to one of the situations we considered in interpreting No. 14. $X$ 's resolution is still divided and incomplete. $\mathrm{He}$ is still ambivalent; in many ways he is still the man he was in No. 6 and No. 8. Fortunately ${ }^{45}$ he is not a murderer with regrets and remorse but only a man who has come very close to being one. He is protected from or relieved of some moral blame by the collapse of the ontological matrix required for the completion of his murderous intent. X's moral blameworthiness under 15a must, nevertheless, be substantially greater than it is under No. 14 , no matter how we construe $X$ 's motives in No. 14. There is an incremental rise in $X$ 's blameworthiness as we move from the interpretation of No. 14 as motivated by $X$ 's respect for law to No. 14 as motivated by prudence. In No. 14 his being and doing are largely decisive; in No. 15, however, his intended action is truncated by the collapse of the larger ontological matrix for which $X$ has far less responsibility. Since $X$ has far less to do with the truncation of his action in No. 15 than with his own termination of his action in No. 14, there is no basis for reducing his moral blameworthiness in No. $15 \mathrm{~b}$ at all, or in

45 I used the word "fortunately" in order to assert again the shocking fact that luck, accident, or fortune plays important and partially determinative roles in the shaping and assessing of moral responsibility. 
No. 15a more than slightly, insofar as it is based upon elements of voluntary responsibility. But $X$ 's blameworthiness based on elements of status responsibility is not substantially greater in No. 15 than in No. 14, though it rises sharply in No. 16.

In No. $16 X$ 's act is fulfilled, completely realized. His intention and volition are fully and accurately expressed in and supported by the ontological matrix which includes his brother's act of eating and digesting and the poison's causal efficacy. $X$ would not and could not be a murderer without the support of this or some other matrix over which he has no control. In No. 16 there is no increment of intention, determination, or voluntariness in X's action over what was present in No. 15b; the increase in his moral blameworthiness in No. 16 over No. $15 \mathrm{~b}$ must come therefore from an increase in his status or ontological responsibility. The fit of intention and volition to the ontological matrix is perfect: the full action is expressed in this absence of disrelation between intention and occurrence, between volition and being. The full action is morally imputed to $X$ because the person of $X$ is so transparently present in this fusion of doing and being.

Another sort of disrelationship between action and intention is introduced by No. 17 (for the sake of brevity we will concentrate on No. 17b). Here we observe the extension of an action beyond the limits intended by and directly influenced by the agent. We may suppose that $X$ had no relatives or friends in the city other than his mother and brother; we may likewise suppose that neither the mother nor the brother had friends in the city; and finally, we may suppose that $X$ put his mother on a train to another city far distant from his own on the very day the action took place. Now $X$ 's brother cannot be blamed for sharing with his mother a meal that he believed to be wholesome: he was neither purposive, knowing, reckless, nor negligent in feeding her the poisoned eggs. But what shall we say about $X$ ?

We may assume that $X$ was intensely (though quite properly and non-Freudianly) fond of his mother; we may even trace part of $X$ 's hostility toward his brother to their competition for her affection. Under these quite reasonable suppositions we see that $X$ is as free from moral blame for the death of his mother as his brother is-if we hold to the view that moral offenses are voluntary. $X$ did not intend to kill his mother any more than his brother did. $X$ did not know that his mother was in even the slightest danger of being killed. Far from being negligent or reckless, he took the precaution of recalling that he had put her on the train to another city and watched the train pull out only a couple of hours before his brother arrived. $X$ was not purposive, knowing, reckless or negligent in so far as the poisoning 
of his mother was concerned. It makes no sense to say that killing his mother was his voluntary act.

At this point we must be clear about two facts: first, we know that $X$ is guilty of crime in No. $17 \mathrm{~b}$; second, we know that he is morally blameworthy in No. 17b. These facts are not in doubt. The problem is: What are the essential characteristics of a theory of moral responsibility that can account for these facts?

In law and morals the problem has usually been solved on the basis of a patently inappropriate application of the theory of voluntary responsibility. In this case, for instance, it may be said that $X$ intentionally and voluntarily (with mens rea) served poisoned eggs to a human being in order to kill him. On the basis of this voluntary action-but by the use of a theory of status responsibility $-X$ will be held responsible for the consequences of his illegal and immoral voluntary act, even though these consequences run counter to $X$ 's intentions and desires. Sometimes, of course, the law limits the criminal's responsibility to the foreseeable consequences of his act or to those consequences which a reasonable man in his position would have foreseen. (The law is not particularly troubled by the fact that a reasonable man either would not be in the criminal's position or, if he were, would no longer be reasonable.) But I feel sure that most lawyers, jurymen, and moralists would hold $X$ morally and criminally responsible for the extension of his action in No. $17 \mathrm{~b}$, despite the fact that $X$ did not intend what happened, nor could he nor any reasonable man have foreseen these consequences. $X$ would be blamed despite the fact that it would be morally objectionable to blame him on the basis of a reasonable and consistent application of the view that moral offenses must be voluntary. ${ }^{46}$

I firmly believe that $X$ is responsible and blameworthy for what happened in No. 17. But the justification for holding $X$ responsible must be on grounds of his status or ontological responsibility. $X$, like all persons, is dependent in action upon a matrix which may truncate, fulfill, or extend his action in such a way that his action is concretized in a way that may coincide with or be in disrelation to his plan or intention. But the action-as it comes to be whether in or out of accord with his intention and volition-is his action. There is no basis for crediting him with his virtuous actions in perfect relation to his intention unless his person and responsibility are enlarged to include elements of the ontological matrix over which he has at best limited control. Indeed, the ontological matrix is a part of his own person patently inadequate. Legal fictions are simply ad hoc corrections to defective legal theories. 
no matter how narrowly he defines it. His volition is never independent of the limiting conditions of his intelligence, knowledge, imagination, emotionality, and energy. Limit the person to what is under his voluntary control, and he disappears without trace along with his volition. If we acknowledge a sufficient number of ontological conditions, over which $X$ has no voluntary control, to account for the existence of $X$ and his capacity to act voluntarily, we have already acknowledged to a significant degree his moral responsibility for what he is no less than for what he does.

We extend this basic point only to a minor degree in recognizing the moral blameworthiness of $X$ for being the man who voluntarily contributed to the situation in No. 13 that was transformed without his knowledge, intention, recklessness or negligence-that is without his voluntary participation-into the situation at No. 17b. In No. 17b his voluntary act of killing his brother has been cut short prior to fulfillment. But in No. $17 \mathrm{~b} X$ has the being or status of a murderer. $\mathrm{He}$ is the man who bears the volitional guilt of his brother's murder without the ontological guilt, and he is the man who bears the ontological guilt of his mother's death without the volitional guilt. ${ }^{47}$

I think the line of reasoning used by the court in Suvada $v$. White Motor Company and related cases contains the elements of status responsibility infused with a trace of prior but not present voluntary responsibility and mens rea that $I$ have in mind. $X$ created the risk of poisoning someone other than his brother-however slight, nonnegligent and nonreckless that risk might be-in order to reap the benefits of his brother's death, just as the defendants in Suvada built, advertized, and sold for profit machinery which created an inadvertent risk. $X$ would have gladly accepted moral praise for the philanthropic use of his brother's estate, had he inherited it; being rich would have given him the ontological basis for certain moral virtues which might be lacking without the estate. The defendants in Suvada may be well respected for the philanthropy which rests on the ontological basis of their risk-creating manufacturing and selling.

The consequences of $X$ 's action in No. 13 are outlined in No. 17. $X$ is responsible for No. 17. No. 17 describes his action, not because of anything he did at No. 17 but because he is at No. 17 the man who did what No. 13 describes. We find the person of $X$ in No. 17 only because in No. 17 he is the same man whose person was expressed in

47 By recognizing X's mixed responsibility, we can assess the full quality of his mother's death, despite the fact that we lack the precise noun, adjective, or adverb to articulate its quality. Her death was not quite a murder, but neither was it mere manslaughter; certainly it was not accidental homicide. 
No. 13. Status responsibility rather than voluntary responsibility justifies our blaming him for No. 17. But his status responsibility in No. 17 derives from his mixed responsibility in No. 13.

Before considering a serious objection which Hart might raise to this line of reasoning, let us consider the subtle responsibility of $X$ 's brother in No. $17 \mathrm{~b}$. He is the man who gave the poison to his mother. His position is like that of the mother who takes thalidomide as a sleeping potion and gives birth to a deformed child, or of a man who kills the child that suddenly runs in front of his car. In thinking of his role in his mother's death, $X$ 's brother is not tortured as the thalidomide mother must be with the thought that she bought her ease at the possible risk of harming her child. Nor is he troubled, as the unfortunate driver is, with the thought that by participating in a vehicular civilization and doing little or nothing to improve the safety features of our streets or cars, he has run the risk of killing a child. There are no antecedents to $X$ 's brother's action which contain any traces of voluntary personal involvement-none that might have contributed to or colored his action in No. 17b. His volitional innocence, and his good fortune perhaps, leave him in status innocence as well. It is a precarious innocence, however, that could be compromised by his having thought "What a disgusting old lady" just before he handed her the eggs intended for himself.

\section{C.}

In offering $m y$ interpretation of the largely ontological basis rather than the voluntary basis of $X$ 's responsibility in No. 17 , I have been troubled by an objection that Hart might reasonably raise. Suppose we were to ask $X$ if he could establish the conditions which on Hart's view would excuse him from all moral blame in No. 17b. $X$ could certainly claim that No. $17 \mathrm{~b}$ was completely unintentional insofar as he was concerned. But could $X$ claim that he had taken every possible precaution? Would Hart say that there was one obvious precaution $X$ had deliberately ignored-namely, the precaution of leaving the poison out of the eggs?

The objection looks formidable but its plausibility actually rests on the details of No. 17 and not on the issues of responsibility. Suppose, for instance, that X's brother had been Adolf Hitler and that No. 17b took place in 1943. We might all agree that $X$ was an unlucky hero, like Colonel Staufenberg, but could we fail to blame him, at least in some moderate degree, for his mother's death? When $X$ takes upon himself the status of an assassin, as in No. 13 (assuming that the brother is Hitler), he establishes the ontological basis for his personal, 
moral involvement in what follows, even though it is not a voluntary or intentional or negligent consequence of his action in No. 13, and even though his action in 13-at the last moment it is to any degree voluntary-is morally good!

Perhaps the point can be seen with greater force if we consider a continuum in which the agent's immediate action is not morally or legally wrong or blameworthy. Following the conventional views of contemporary Americans and Europeans, let us suppose a) that sexual intercourse between consenting adults of the opposite sexes is not morally offensive or blameworthy, and b) that it is morally offensive and blameworthy to be the parent of a bastard child. If we take these moral suppositions for granted, let us consider the following alternative situations in which-unless otherwise noted- $Y$ is a healthy, young, unmarried woman:

1. $Y$ is raped and becomes pregnant.

2. $Y$ is so seriously ill that advanced pregnancy would be fatal; she takes every contraceptive precaution, but becomes pregnant.

3. $Y$ has no idea what causes babies, has intercourse without being aware of the possible consequences and becomes pregnant.

4. $Y$ with full knowledge of the cause of pregnancy takes all contraceptive precautions, has intercourse, and becomes pregnant.

5. $Y$ with full knowledge is negligent in the use of contraceptives and becomes pregnant.

6. $Y$ with full knowledge but in the ecstacy of love uses no contraceptive and becomes pregnant.

7. $Y$ with full knowledge uses no contraceptive because of religious scruples and becomes pregnant.

8. $Y$ with full knowledge, complete self control, and no scruples against contraceptive methods, does not use them and becomes pregnant, not caring one way or the other.

This series is ordered on a continuum of undiminished or increasing volition as we move from involuntary to clearly voluntary action without extending the continuum to include any actions that involve the conscious intention to become pregnant.

Accordingly $Y$ never intends to become pregnant, and in situations No. 1 through No. 4 she is neither reckless nor negligent. Can she not claim then that insofar as the first four situations are concerned, her action is morally blameless because unintentional and that she took every possible precaution.

Suppose Hart were to reply that she is confused about the action which requires justification. She intentionally had intercourse in all 
but the first situation. But if she did not provoke the rapist, she is not to blame for anything in No. 1. And since she took every precaution to avoid becoming an unwed mother, she has done nothing wrong in Nos. 2, 3, and 4, for there is nothing morally blameworthy, ex hypothesi, about intercourse. At this point $Y$ will have to say: "But Professor Hart, I am pregnant. As things stand now I shall become morally blameworthy for being the mother of a bastard child."

How is Hart to cope with this situation on his theory of the voluntary character of moral offenses? The intercourse is not wrong, and on the voluntary theory of action and responsibility there is no act of becoming pregnant or of growing a baby. One does not become pregnant voluntarily or voluntarily develop a child in the womb. Hence, on this theory, there is no way that one can be morally blameworthy for becoming pregnant or producing a child except as a consequence of voluntary intercourse. But since we hold that intercourse is not wrong, we must then acknowledge the absence of any wrongdoing, if pregnancy follows when all precautions have been taken. One cannot admit that intercourse is morally right per se and then argue that in order to take all precautions against pregnancy one must refrain from intercourse. When one recognizes that intercourse is morally acceptable, he is committed on the voluntary theory to withholding moral blame for pregnancy if all precautions short of sexual abstinence have been taken. On Hart's theory we have the absurd consequence that no moral blame can attach to having a baby out of wedlock provided it was not planned and all precautions short of abstinence were observed.

The absurdity is even more glaring with regard to the moral blameworthiness of fathers who have children out of wedlock. Impregnating, like being impregnated, may be a highly personal act. But it can be so only on a view that takes seriously the notion of an organic mode of personal action and organic intentionality. Procreation cannot even be accomplished physically by the father; so far as he is concerned, it is an act by proxy, and the proxy is a germ cell completely detached from his body. If he has any effective intent in procreation beyond intercourse, it is by means of the organic intention of his proxy. To speak of his procreating voluntarily makes sense on an enlarged view of voluntarism which absorbs a considerable portion of Bergsonian organistic intention. But this Bergsonian view is not compatible with Hart's metaphysical asceticism. On his view the man who has intercourse without intending to have a child and who sees to it that proper contraception is used, must be free of all moral blame in fathering a bastard child. 
Further evidence for the theory of responsibility $I$ am urging is that it does not fall into this absurdity with regard either to $Y$ or her male partner. On my view it is primarily the being of the father and the mother, not their voluntary act of intercourse, that provides the basis of their parental obligations and their blameworthiness for being parents out of wedlock. Like $X$ in No. 13 and No. $17 \mathrm{~b}$, the parent of a bastard child is responsible for being the person who set in motion factors that culminate in the development and birth of the child. There is a far greater degree of personal involvement in this situation, however, because of the organic expression of personality that is absent in the example of the poisoned eggs. The personal agents of the voluntary act of intercourse are present in procreation, not as chemical or mechanical forces, but as the living, organically intentional, fertilized egg with their personal genetic structure.

Both fathers and mothers must recognize and accept their responsibility for what they are and for what they become as a consequence of what they are, even when there is no bond created by intention or negligence that unifies what they are with what they become by reference to what they do.

Action broadly defined is that which binds past to present to future; it is the substance of personal duration. We destroy this bond or deny its existence by accepting a narrow voluntaristic definition of action and responsibility, and we lose the continuity of the moral self. Kant's old problem of providing some basis for moral continuity in a self which is unqualified in volition, except as it qualifies itself through the voluntary action in every moment, will be our problem unless we accept the necessary minimum of status elements in our concept of moral obligation and responsibility.

The adherents of voluntary responsibility cannot evade these diffculties by holding that $Y$, after becoming pregnant, is responsible only for doing whatever is necessary to avoid having the child out of wedlock; by holding, that is, that $Y$ is excused from all moral blame if she makes every effort either to have an abortion or get married. It would be difficult to justify abortion in any but the first or second instances, and even the first case poses some problems if one recognizes intrinsic value in human life. ${ }^{48}$ Nor is the alternative of marriage universally satisfactory: it may be impossible for $Y$ to marry, or any possible marriage might be morally more objectionable than the offense of having

48 I suppose it can be argued that the neglect and abuse to which a bastard child is often subjected can be avoided by killing the child. The legitimacy of the argument might be more apparent, however, if it were urged by the illegitimates. My experience is that natural born bastards are just about as intent on living as self-made ones. 
the child out of wedlock. The father may have died; $Y$ may conclude after careful deliberation that the father or any man whom she could marry would exert a morally corrupting influence on the child; or $Y$ or the father may conclude that to marry would be so destructive of career to which an obligation is also owed that it is morally better to accept the blame for having the child out of wedlock without compounding moral offense by an immoral marriage. However we turn the problem around, there is no way of establishing the moral responsibility of $Y$ or her partner for the unintended consequences of their nonnegligent intercourse, without supplementing the voluntary theory of responsibility by the introduction of status elements; yet there is no way of denying their responsibility without abandoning our initial premise that it is morally wrong to have a bastard child. ${ }^{48}$

But suppose we take the argument one step further. Let us drop the supposition that it is wrong to be the parent of a bastard childa dubious supposition despite its conventional support-and hold instead merely that it is wrong to be voluntarily, recklessly, or negligently the parent of a child for which reasonably adequate care and provision has not and cannot be made. With this revision, what shall we say of the expectant mother who has not been negligent or reckless in the use of contraceptives and who was reasonably confident of their adequacy. If moral offenses must be voluntary, she can be morally responsible only for future voluntary acts-for example, the neglect of her developing child. But our expectant mother may insist: "Since I am not voluntarily (or morally) responsible for being pregnant, I refuse to alter my life because of this fact. And if I am blamed because I refuse to care for myself or my child, those who blame me must blame me in violation of Hart's principle that moral offenses are essentially voluntary. Those who blame me must blame me for refusing to meet a standard which, though appropriate to voluntarily expectant mothers, is not appropriate to an involuntarily pregnant woman like me. On the voluntary conception of moral responsibility, I am no more obligated to care for my child than to care for a wart on my nose."

I assume that we agree that this pregnant woman has an obligation to care for the child she is carrying. But what reply can we make to her statement? If the thesis that moral offenses must be voluntary is sound, and if (having done her best to avoid pregnancy) she is not

49 The degree of $Y$ 's status responsibility in having a child out of wedlock will vary in the situations from No. 5 to No. 8 according to the degree of voluntariness and the extent of negligence or recklessness in the use of contraceptive devices. These further considerations are left to the reader. 
voluntarily pregnant, how can she be blamed morally for failing to meet a standard appropriate to her actual status (which she tried to avoid) but totally inappropriate to a nonpregnant status (which she voluntarily but ineffectually chose). In terms of the status and conditions she voluntarily chose, she is not required to care for her developing child. But because of a change in her status-through no choice or fault of her own-she is now obligated to care for it. She can claim, on the basis of the voluntary thesis, that since she did not choose the condition on which the new obligation is based, she does not choose to violate that obligation. Admittedly, she chooses to act in violation of the obligation to care for the child. But since she did not choose the condition on which the obligation depends, she does not choose to violate the obligation; hence, she violates no moral rule binding on her under the voluntary thesis.

Here we confront an essential feature of moral obligation which the voluntary thesis does not adequately account for-namely, moral obligation may obtain whether or not it is chosen. Moral obligation obtains according to the nature and the situations of persons. While it is true that one's obligation may be changed by the degree to which he has voluntarily altered his nature or his situation (through education, recklessness, or contract, for examples), moral obligation normatively regulates his action whether his nature and condition are within his voluntary control or not.

In short, the context in which he is held to account for his voluntary actions (which are by no means purely voluntary but which, as I have shown, contain status elements) is an involuntary, necessary one. And if, in accordance with the voluntary thesis, one could excuse himself from an offending action by showing that he could not help it, it should be possible always to excuse oneself whenever he finds that he is of a nature or in a situation contrary to his voluntary control. For one can say: "I cannot help being in this situation, and if I were not in this situation, my offending conduct-even if voluntarywould not offend."

The fundamental basis of moral obligation is found in the nature and situation of the agent. These status elements are preconditions of the possibility of moral offense. And these preconditions are the consequences of prior voluntary actions only in some but by no means in all instances. The status elements, which define the agent's obligations, often arise without help from and despite the intentions of the agent; and they can never result merely from his voluntary choice. Hence, either we must abandon moral obligation as meaningless or we must abandon the voluntary thesis. Accepting the latter alterna- 
tive, I hold (returning to our example) that the expectant mother is liable to judgment by an involuntarily imposed standard because she is in an involuntarily contracted condition of pregnancy. And I hold that her offense, if she violates the duty to care for herself and her baby, is not an essentially voluntary offense because it is defined by a standard which is involuntarily imposed on the basis of her involuntarily established condition.

The foundation of moral obligation (and therefore of moral offense) in status is fundamental. I may be privileged to argue that since I did not choose my skin color, I will alter it; or that since I do not voluntarily have a crooked nose, I will have it bobbed. But I cannot argue that since I did not choose my sex, I will have it changed; ${ }^{50}$ or that since I did not choose to become a father, I will refuse to support my child. Either there are no moral obligations or moral obligations impose restrictions on my conduct because of my nature and my situation even if neither is a product of my voluntary choice.

D.

Hart says, at the conclusion of the quotation we have been examining: "In morals ' $I$ could not help it' is always an excuse, and moral obligation would be altogether different from what it is if the moral 'ought' did not in this sense imply 'can.' "We have already seen the confusion and artificiality involved in trying to show that "I could not help it," and I have argued that there are many situations in which "I could not help it" is not an excuse. Consequently, I have argued that Hart's thesis of the voluntary character of moral offenses itself distorts the meaning of moral obligation. But the question remains whether, in rejecting the claim that "I could not help it" as always an excuse, we have transformed moral obligation into something altogether different from what it is.

Two things must be said. First, even if we radically change the view of obligation defended by Hart, it does not follow that we shall alter the character of moral obligation-we may merely articulate its nature

50 Anonymous v. Weiner, 50 Misc. 2d 380, 270 N.Y.S.2d 319 (Sup. Ct. 1966) (denial of application to change sex designation on birth certificate to correspond with results of medical operation which changed petitioner's sex). See H. Benjamin, The Transsexual Phenomenon (1966) for a medical discussion and defense of the right to alter one's sex. But Dr. Benjamin supports surgical transformation of sex in only very unusual situations where there is a serious psychological disturbance in gender role and gender orientation. See also Benjamin, Clinical Aspects of Transsexualism in the Male and Female, 18 AM. J. of Psychotherapy 458 (1964); and Benjamin, Nature and Management of Transsexualism: with a Report on 31 Operated Cases, 72 Western J. Surgery, Obstetrics \& GyNeCology 105 (1964). 
more precisely. This is not necessarily a logical issue about the meanings of words, despite the fact that Hart, and linguistic philosophers generally, so regard it. Second, in any case I have not altogether transformed the character of moral obligation for I have tried to present and defend the view that "I could not help it"-though not always an excuse-would in many circumstances excuse one from the most severe degree of moral blame. One is excused from the degree of moral blame appropriate in cases of consciously voluntary wrongdoing provided one can show that what he did was not fully voluntary. On this point the traditional voluntaristic position on moral obligation is not altered.

But I have also argued that the application of ethical rules and principles in the absence of a theory of ethics containing: 1) a concept of responsibility which provides for a continuum of increasing and decreasing status and voluntary elements, and 2) a system of substantive values to overcome the abstractness of formalism, will never sustain a notion of moral obligation or responsibility adequate to account for the subtle but extensive range of guilt and innocence, virtue and vice, praise and blame in personal action. Without these factors no notion of moral obligation or responsibility can be adequate to account for the fundamental moral virtue of accepting one's being or the fundamental moral offense of refusing to do so. And it is important to note that a part of the virtue of accepting one's being lies in the acceptance of one's partial blameworthiness for what one is.

Theories like Hart's or Kant's, which restrict responsibility to voluntary conscious acts and limit moral offenses to consciously intended or reckless acts in violation of principles or rules, can never give content or substance to moral action or to the moral person. Human choice is not something isolated from the choosing person. Rather it is a thoroughly organic mode of self-expression and self-discovery. There are gradations of choice and degrees of voluntariness; at every instant, however, even in those acts of purest, freest, most voluntary choice, choice depends upon the being of the person and the matrix of his action, both of which contribute to the moral quality of the person and to the moral quality of his action even though neither is to any great extent subject to his voluntary control. We shall never find a person in his action unless his doing is his being, or at least a part of it. We have neither understanding of man nor a basis for moral and legal judgment of him, unless we recognize the human person as a unity of being and doing. This cannot be done without partially reshaping the concepts of moral obligation and responsibility in order to free them of the limitations of simplistic voluntarism. We must reshape the concept of responsibility and the notions of intention, awareness, and choice so that they apply in varying degrees over the entire range of personal 
existence. When this reshaping is done, we shall have a better understanding of moral obligation and moral and criminal responsibility.

The voluntary conception of moral obligation and responsibility appropriately characterizes maximally personal actions. But an adequate conception must appropriately characterize all degrees and kinds of personal action from the most voluntary to the least voluntary. For this, a theory of responsibility is required in which there is a fusion of status or ontological and voluntary elements, and in which moral obligation is understood as applying not merely to the volition but to the being of each person.

Such a theory, when fully developed, will make necessary the reformulation of the judge's instructions to jurors in criminal cases. Jurors will no longer be asked to say "Guilty" or "Not guilty." Rather jurors will be asked to find from among four to eight clearly formulated types of personal action, the type most nearly descriptive of the behavior of the accused. And on the basis of the jury's finding of the being-and-doing of the accused, a revised criminal code will prescribe punishment, treatment, or release. Throughout, however, a defendant in a criminal case will enjoy full protection of legal counsel and the procedural guarantees of the criminal law. For the recognition, in such a theory, of an attenuated element of mens rea and actus reus in the so-called status crimes of drug addiction and chronic alcoholism, etc., will preclude the withering away of the criminal law and the abandonment of those accused of such crimes to the less carefully controlled and perhaps less just procedures of medical boards.

When this theory is fully developed, it will account for the moral virtue of accepting one's being, and the moral blameworthiness of one's refusal to do so. It will make clear, moreover, that part of the virtue of accepting one's being lies in the acceptance of one's blameworthiness for what he is. We may even be able to understand the doctrine of original sin ("In Adam's fall we sinnèd all") as well as Oedipus' ultimate self condemnation expressed in Sophocles' play by his act of blinding himself. 